\title{
Mutagenicity Assay of an Organophosphate Pesticide, Monocrotophos in Mammalian in vivo Test System
}

\author{
S. P. Bhunya and B. C. Behera \\ Laboratory of Genetic Toxicology, P. G. Department of Zoology, \\ Utkal University, Bhubaneswar-751 004, India
}

Accepted December 23, 1987

Amongst the environmental chemical pollutants with possible health hazards to man, no doubt the pesticides play an important role, since residues of these chemicals may remain in food and being ingested by humans. The great number of pesticides and their different formulations used today make it difficult to select those that are genetically active i.e. induce mutations or recombinations. Mutagenicity testing has assumed increasing importance in the context of society's responsibility not only to conserve the genetic material as a whole but also to protect our own hereditary material from an artificial increase in the frequency of detrimental mutations.

Genotoxicity of a number of organophosphate pesticides has been studied in plants and animals (Epstein and Legator 1971, Ahmed and Grant 1972, Shirasu et al. 1976, Nehez et al. 1982, Wild 1975, Bhunya and Behera 1984, Hanna and Dyer 1975, Amer and Fahmy 1982, Behera and Bhunya 1987). Monocrotophos is one of the commonly used organophosphorus insecticides having acaricidal property too. Recently monocrotophos has been reported to be mutagenic in peanuts (Jaganmohan et al. 1985). As far as the knowledge of the present authors goes, mutagenicity of monocrotophos has not been studied in mammalian system. The present communication provides the information regarding the cytogenetic effects of monocrotophos (Nuvacron) on the bone marrow cells and sperm shape of mice.

\section{Materials and methods}

Test Animal: Male and female individuals of inbred mice (Swiss strain) of age group 10-12 weeks were used in the present investigation.

Test Chemical: Technical form of monocrotophos (Nuvacron), O, O-dimethyl-O (2 methyl carbanmoyl-1-methyl vinyle) phosphate was donated by Hindustan Ciba-Giegy India Limited. The structure of this compound is as follows. The solution of the chemical was prepared by glass double distilled water. Equal volume of g.d.d. water served as control.

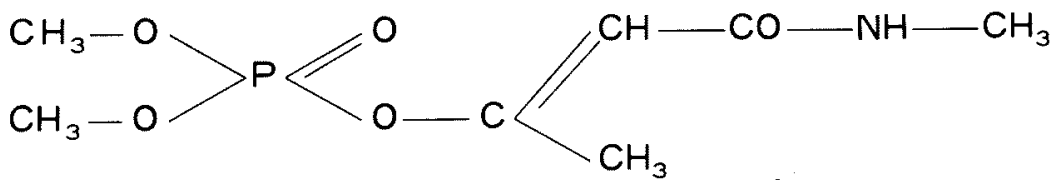

Structure of monocrotophos

Dose: Three different doses like $5,2.5$ and $1.25 \mathrm{mg} / \mathrm{kg}$ b.w. have been used.

Bone Marrow Chromosome Assay

For this assay all the three doses were used through i.p. and the highest dose $(5 \mathrm{mg} / \mathrm{kg})$ 
through p.o. and sc also. The time of exposures were 6,24 and $48 \mathrm{hrs}$ for acute dosing and $120 \mathrm{hrs}$ for chronic dosing. In chronic series the highest dose was fractionated into 5 equal parts and each part was administered repeatedly for 5 times at the interval of $24 \mathrm{hrs}$ in between and animals were sacrificed after $24 \mathrm{hrs}$ following the last dose. Cytological slides were prepared following usual colchicine-sodium citrate-air drying-Giemsa schedule.

\section{Micronucleus Assay (MN)}

All the doses of the chemical were administered i.p. Each individual received the dose twice with a time gap of $24 \mathrm{hrs}$ in between and was sacrified after $6 \mathrm{hrs}$ following the second dosing. Slides were prepared from the bone marrow cells according to Schmid (1976) modified by Das and Kar (1980). Assessment for the incidence of MN was done separately for Polychromatic erythrocytes (PCEs), Normochromatic erythrocytes (NCEs) and nucleated cells and per animal 1000 cells of each type were examined.

\section{Sperm Shape Abnormality Assay (SSA)}

Each individual was injected i.p. subacutely 5 times for all three doses, with an interval of $24 \mathrm{hrs}$ in between and specimens were sacrificed after 35 days following the Ist injection. The caudae epididymides were dissected out and placed into a petridish containing $0.9 \%$ saline. After dicing with a scissors, the suspension was gently pipetted five to six times. Slides were prepared from this suspension by spreading a drop over the slide with the edge of another slide and stained in $1 \% \operatorname{eosin} \mathrm{Y}(\mathrm{BDH})$. Per animal 500 sperms were scored; the sperm abnormalities were categorised, wherever possible, according to Wyrobek and Bruce (1975).

Bone marrow chromosome aberration, MN and SSA were scored from slides under code. The proportion test ( $\mathrm{Z}$ value) was used for all treated results to see whether the treated values deviated significantly from control or not.

\section{Results}

In the treatment group different general effects like corrosiveness, chromatin stretching and centromeric separation were observed in the bone marrow chromosomes. Aberration like chromatid gaps and breaks, isochromatid gaps, rings and fragments have also been recorded (Fig. 1). Quantitatively highest dose induced highest percentage of aberration $(5.66 \%)$ after $24 \mathrm{hrs}$ exposure. Regarding route sensitivity chemical has been found to be most effective when treated through i.p. The fractionated dose when treated repeatedly (chronic) produced less effect than the equivalent acute dose. All the quantitative data of bone marrow chromosome aberration have been presented in Table 1.

Table 2 shows the frequency of $\mathrm{MN}$ in the bone marrow cells. There were no significant differences from control for any of the treatment groups. The shape of the micronuclei were either dot or ring shaped (Fig. 2). The size of the micronuclei in different cell types ranges from $1 / 10$ th to $1 / 5$ th of the cell size. Quantitatively frequency of MN was highest in PCEs and lowest in nucleated cells.

Frequency of SSA in all treated groups has been summarized in Table 3. Various types of sperm head abnormalities like amorphous, banana type, beak shaped acrosomal end, forked acrosomal end and some with double tailed type were noticed (Fig. 3). Quantitatively the highest frequency of sperm abnormalities was induced by the highest dose and least by the lowest dose. In this assay all the treated values significantly differed from the control. 


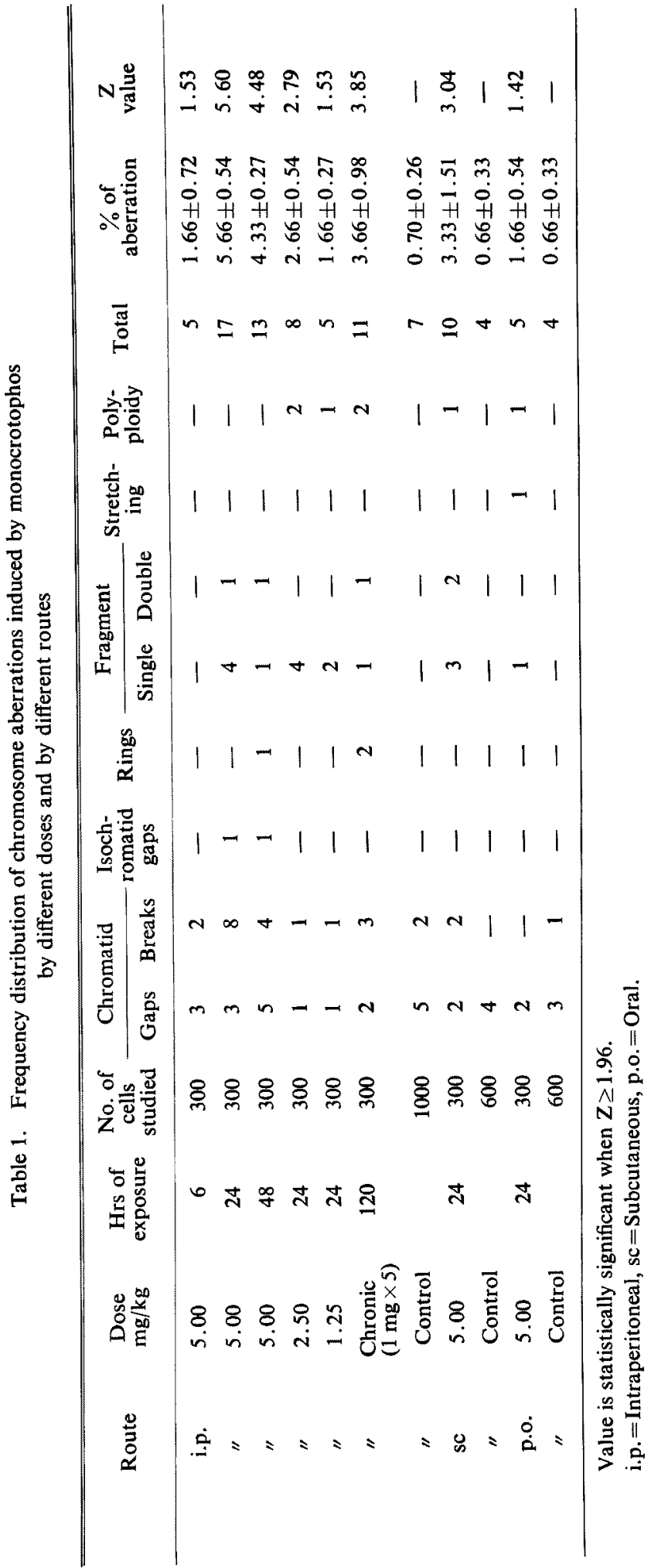




\section{Discussion}

It is evident from the present results that monocrotophos is a mutagen in the present test system. Significant variations of the treated results from controls have been recorded for bone marrow chromosome aberrations and SSA but not for MN. However, some of the MN results are higher than the controls (Table 2). Decrease of chromosome aberration frequency in late hours and with lower doses, was probably due to the non-availability of critical concentration of the chemical at the target molecules (DNA and protein) and due to elimination of the metabolites from the body with time. Out of the 3 routes of administration the

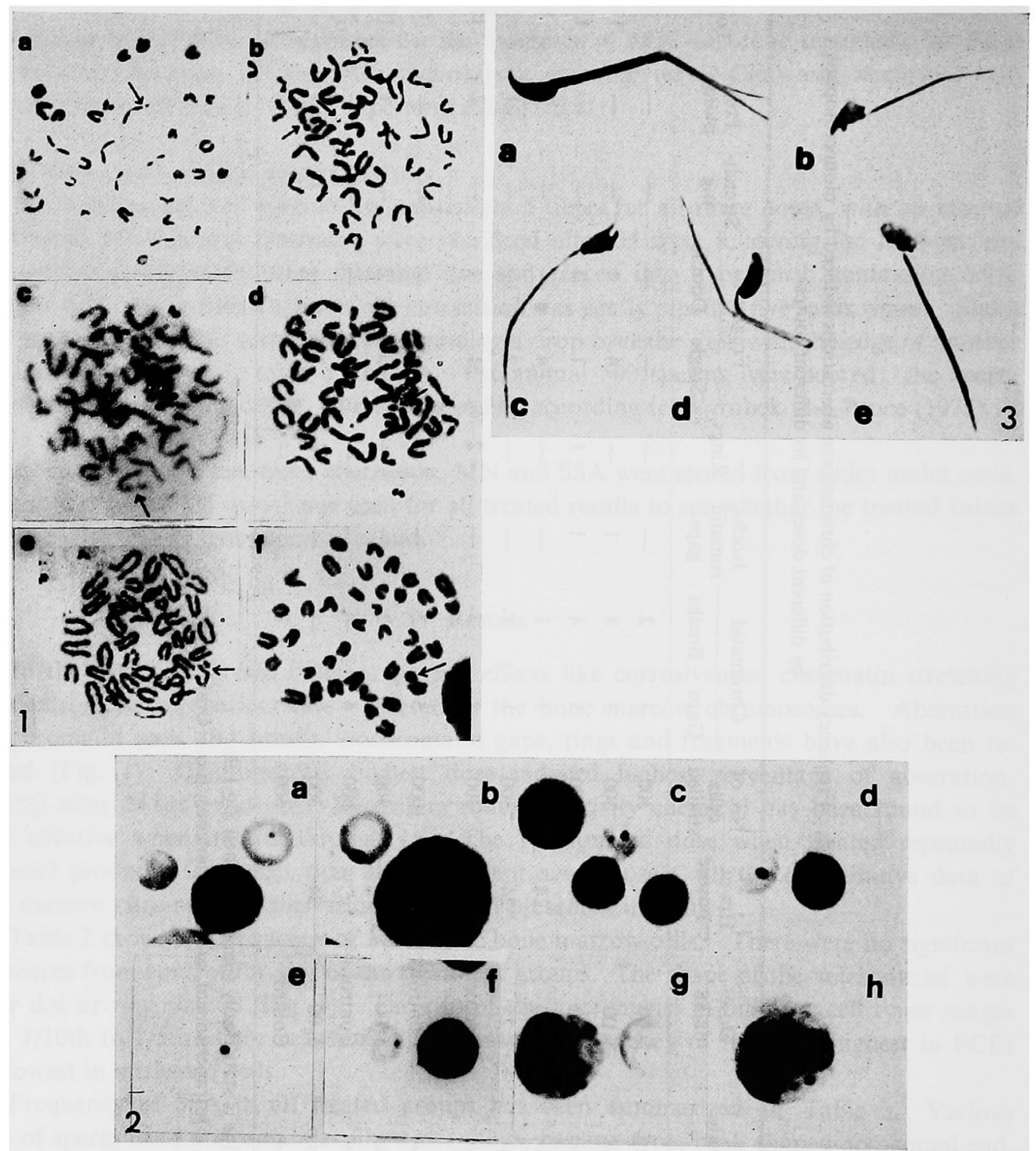

Figs. 1-3. 1. Chromosomal aberration. (a), (b), chromatid gap and fragment; (c), (d), chromatid break; (e), double fragment of unknown origin; (f), ring chromosome. 2. Photomicrographs showing micronucleated erythrocytes and nucleated cells. (a)-(d), PCEs with MN; (e)-(f), NCEs with MN; (g)-(h), nucleated cells with MN. 3. Photomicrographs showing sperm shape abnormalities. (a), double tailed sperm; (b), forked acrosomal end; (c), beak shaped acrosomal end; (d), banana shaped head; (e), amorphous type head. 
compound is cytogenetically most active when treated through i.p. and least through oral (Fig. 4). Production of least effect through oral may be due to the least absorption in the oral route for particular pharmacodynamic porperties of the compound. The mechanism of action of monocrotophos at nucleic acid level is not properly known. However, organophosphorus pesticides have alkylating properties (Wild 1975). So DNA alkylation might be

Table 2. Incidence of micronucleated bone marrow cells induced by monocrotophos

\begin{tabular}{|c|c|c|c|c|c|c|}
\hline $\begin{array}{l}\text { Dose } \\
\mathrm{mg} / \mathrm{kg}\end{array}$ & $\begin{array}{l}\text { No. of } \\
\text { animals }\end{array}$ & $\begin{array}{c}\% \text { of } \\
\text { polychromatic } \\
\text { erythrocytes } \\
\text { (PCEs) with } \\
M N \pm S E \\
\text { (A) }\end{array}$ & $\begin{array}{c}\% \text { of } \\
\text { normochromatic } \\
\text { erythrocytes } \\
\text { (NCEs) with } \\
\text { MN } \pm \text { SE } \\
\text { (B) }\end{array}$ & $\begin{array}{c}\% \text { of PCEs } \\
+ \text { NCEs } \\
\text { with } \\
\text { MN } \pm \text { SE } \\
(\mathrm{A}+\mathrm{B})\end{array}$ & $\begin{array}{c}\% \text { of } \\
\text { nucleated } \\
\text { cells with } \\
\mathrm{MN} \pm \mathrm{SE} \\
\text { (C) }\end{array}$ & $\begin{array}{l}\text { Total } \% \\
\text { of } \mathrm{MN}\end{array}$ \\
\hline 5.00 & 3 & $0.40 \pm 0.04$ & $0.16 \pm 0.02$ & $0.28 \pm 0.01$ & $0.13 \pm 0.03$ & $0.23 \pm 0.00$ \\
\hline 2.50 & 3 & $0.16 \pm 0.05$ & $0.10 \pm 0.05$ & $0.13 \pm 0.05$ & $0.13 \pm 0.07$ & $0.13 \pm 0.07$ \\
\hline 1.25 & 3 & $0.10 \pm 0.05$ & $0.06 \pm 0.03$ & $0.08 \pm 0.01$ & $0.03 \pm 0.03$ & $0.06 \pm 0.00$ \\
\hline Control & 3 & $0.20 \pm 0.05$ & $0.10 \pm 0.05$ & $0.15 \pm 0.05$ & $0.06 \pm 0.03$ & $0.12 \pm 0.01$ \\
\hline
\end{tabular}

All the values are insignificant statistically.

Table 3. Monocrotophos induced sperm shape abnormality in mice

\begin{tabular}{cccccc}
\hline $\begin{array}{c}\text { Dose } \\
\mathrm{mg} / \mathrm{kg}\end{array}$ & $\begin{array}{c}\text { No. of } \\
\text { animals }\end{array}$ & $\begin{array}{c}\text { Total no. of } \\
\text { sperms studied }\end{array}$ & $\begin{array}{c}\text { Total no. } \\
\text { of abnormal } \\
\text { sperms }\end{array}$ & $\begin{array}{c}\% \text { of abnormal } \\
\text { sperms } \pm \mathrm{SE}\end{array}$ & $\begin{array}{c}\mathrm{Z} \\
\text { value }\end{array}$ \\
\hline 5.00 & 3 & 1500 & 129 & $8.60 \pm 2.61$ & 10.25 \\
2.50 & 3 & 1500 & 98 & $6.53 \pm 1.10$ & 7.62 \\
1.25 & 3 & 1500 & 77 & $5.13 \pm 1.01$ & 5.60 \\
Control & 3 & 3000 & 62 & $2.06 \pm 0.66$ & - \\
\hline
\end{tabular}

Value is statistically significant when $Z \geq 1.96$.

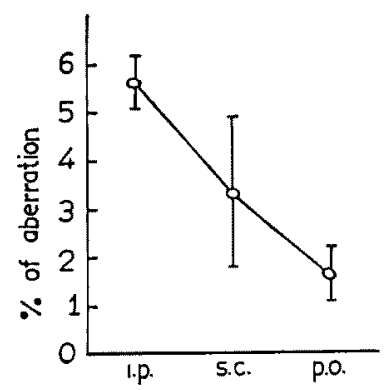

Fig. 4. Monocrotophos induced route dependent bone marrow chromosome aberration.

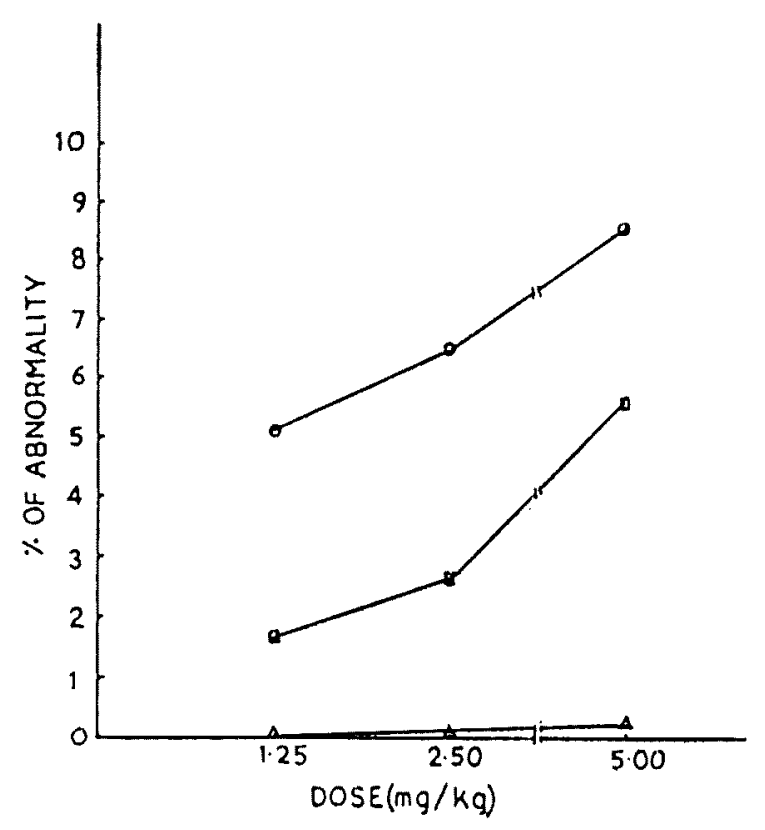

Fig. 5. Monocrotophos induced bone marrow chromosome aberration $(\square-\square)$, micronucleus $(\Delta-\Delta)$ and sperm shape abnormality $(\mathrm{O}-\mathrm{O})$. 
one of the reasons for the production of chromosomal aberrations and so also for $\mathrm{MN}$ formation. Effects like stretching and corrosive action of chromosomes indicate that the pesticide may have acted upon the protein moiety of the chromosome. Occurrence of chromatid type aberrations indicates that the chemical acted upon the stages following $G_{1}$ phase of cell cycle.

Sperm abnormality is due to changes in the genetic components controlling the process of spermatogenesis (Wyrobek and Bruce 1975, 1978, Krzanowska 1976a, b, Hugenholtz and Bruce 1979, and Kar and Das 1983). This view is contemplated by differential spontaneous incidences of sperm abnormalities in different strains of mice (Bruce et al. 1974, Krzanowska 1976a, Buda and Krzanowska 1978). So the production of higher percentage of abnormalities by monocrotophos may be a measure of the genetic damage caused in the germline cells.

Out of the three assays the relative sensitivity has been found to be: sperm shape abnormalities $>$ chromosomal aberration $>$ micronucleus (Fig. 5).

Since monocrotophos has been found to be genotoxic in the present test system, its restricted use and cautious handling are suggested.

\section{Summary}

In the present study an endeavour has been made to assay the mutagenicity of an organophosphorus pesticide, monocrotophos (Nuvacron) in mouse cytogenetic test system. Cytogenetic assays like somatic chromosome aberration, micronucleus test and sperm shape abnormalities have been done. Different doses $(5,2.5$ and $1.25 \mathrm{mg} / \mathrm{kg})$, different exposure times (6, 24, 48 and 120 hours) and different routes (i.p., p.o. and sc) of administration have been employed. The effects are mostly dose, time and route dependent. Comparision of acute and chronic treatments revealed that the chemical has no cumulative effect. Relative sensitivity of cytogenetic assays has been found to be as sperm shape abnormality>chromosome aberration $>$ micronucleus. Monocrotophos has been found to be mutagenic in the present test system.

\section{Acknowledgements}

Grateful acknowledgements are made to Prof. P. Mohanty-Hejmadi, Head of P.G. Department of Zoology, Utkal University for Laboratory facilities, U.G.C., New Delhi for granting major research project to SPB and Hindusthan Ciba-Giegy India Ltd. for kindly supplying the chemical as gift material.

\section{References}

Ahmed, M. and Grant, W. F. 1972. Cytological effects of the mercurial fungicide panogen-15 on Tradescantia and Vicia faba root tips. Mutation Res. 14: 391-396.

Amer, S. M. and Fahmy, M. A. 1982. Cytogenetic effects of pesticides I. Induction of micronuclei in mouse bone marrow by the insecticide Dursban. Mutation Res. 101 : 247-255.

Behera, B. C. and Bhunya, S. P. 1987. Genotoxic potential of an organophosphate insecticide, Phosphamidon (Dimecron): An in vivo study in mice. Toxicology Letters. 37: 269-277.

Bhunya, S. P. and Behera, J. 1984. Clastogenicity of a fungicide Ediphenphos (Hinosan) in the bone marrow cells of mice in vivo. Cytologia 49: 833-839.

Bruce, W. R., Furrer, R. and Wyrobek, A. J. 1974. Abnormalities in the shape of Murine sperm after acute testicular X irradiation. Mutation Res. 23: 381-386.

Buda, D. and Krzanowska, H. 1978. Types of sperm head abnormalities in five inbred strains of mice (A, AKR, 129, C58, BALB). Zwier. Lab. 15: 63-70.

Das, R. K. and Kar, R. N. 1980. Sodium citrate solution as a substitute for fetal calf serum in micronucleus preparation. Stain Technol. 55: 43. 
Epstein, S. S. and Legator, M. S. 1971. The Mutagenicity of Pesticides, Concept and Evaluation. MIT Press (U.S.A.).

Hanna, P. J. and Dyer, K. F. 1975. Mutagenicity of organophosphorus compound in bacteria and Drosophila. Mutation Res. 28: 405-420.

Hugenholtz, A. P. and Bruce, W. R. 1979. Sperm size abnormalities in homozygous and heterozygous in (5) 9 Rk mice. Can. J. Genet. Cytol. 21: 115-119.

Jaganmohan, M., Khatoon, A. and Bhalla, J. K. 1985. Mutagenic effect of Malathion and Nuvacron on peanuts. (Abstract) 10th Annual Conference, Environmental Mutagen Society of India, Environmental Mutagen and Human Health Problem and Perspective, Feb. 18-21.

Kar, R. N. and Das, R. K. 1983. Induction of sperm head abnormalities in mice by three tranquilizers. Cytobios 36: 45-51.

Krzanowska, H. 1976a. Types of sperm head abnormalities in four inbred strain of mice. Acta. Biol. Care. Ser. Zool. 19: 79-85.

- 1976b. Inheritance of sperm head abnormality types in mice-the role of the $Y$ chromosome. Genet. Res. 28: 189-198.

Nehez, M., Fischer, G. W., Scheufler, H. and Selypes, A. 1982. Mutagenie effects of dimethoate and dimethyldimethoate in dominant lethality test and bone marrow cells of laboratory mouse. Mutation Res. 97: 207.

Schmid, W. 1976. The micronucleus test. In: Chemical Mutagens, Principles and Methods for their Detection. Vol. 4, A. Hollaender Ed. (Plenum Press, New York) pp. 31.

Shirasu, Y., Moriya, M., Kato, K., Furuhashi, A. and Kada, T. 1976. Mutagenicity screening of pesticides in microbial system. Mutation Res. 40: 19-30.

Wild, D. 1975. Mutagenicity studies on organophosphorus insecticides. Mutation Res. 32: 133-150.

Wyrobek, A. J. and Bruce, W. R. 1975. Chemical induction of sperm abnormalities in mice. Proc. Natl. Acad. Sci. (U.S.A.) 72: 4425-4429.

- and - 1978. The induction of sperm shape abnormalities in mice and humans. In: Chemical Mutagens, Principles and Methods for their Detection. Edited by A. Hollaender and F. J. de Serres. Plenum Press, New York 5: 257-285. 